\title{
ENSAIO
}

\section{OS CABOCLOS JÁ CHEGARAM: POR UMA ESCUTA MULTIESPÉCIES DAS VOZES DO ANTROPOCENO}

Andre Luis de Lima Carvalho*

\section{DA GEOLOGIA À PLURIDISCIPLINARIDADE: UM CONCEITO QUE GANHOU VIDA PRÓPRIA}

O presente ensaio propõe discutir a temática do Antropoceno correlacionando Ecologia de Saberes e Epistemologias do Sul à abordagem decolonial e em articulação com a perspectiva multiespécies. Centrado na crítica à doutrina do excepcionalismo humano, sustenta que somente uma aproximação transdisciplinar e radicalmente antiantropocêntrica tem a potência de pensar os problemas epistemológicos e pragmáticos do Antropoceno. Discute a importância da mobilização de novas palavras e conceitos para o enfrentamento da soberba colonial da modernidade a partir de uma escuta sensível dos saberes ameríndios e da valorização da noção de encantamento.

O conceito de Antropoceno foi apresentado ao mundo no ano 2000, ao abrir das portas do terceiro milênio, em uma nota curta no Global Change Newsletters, um boletim do IGPB (International Geosphere Biosphere Programme), programa de pesquisa realizado entre 1987 e 2015 dedicado ao estudo do fenômeno das mudanças globais (CRUTZEN; STOERMER, 2000). A tese central, defendida pelo texto inaugural, apoiada no radical antropo da palavra, era de que a ação humana havia atingido um poder de agência transformadora do planeta equivalente ao de uma força geológica. Os autores, Paul Crutzen e Eugene Stoermer, alertavam o leitor para as ameaças climáticas globais que se avultavam, expondo não apenas a humanidade, mas a própria biosfera, a grande risco, e chamando a comunidade acadêmica para a urgência de responder a essas ameaças. A proposição original de Crutzen e Stoermer era de que o nome Antropoceno substituísse o Holoceno como época geológica atual do planeta. Nesse sentido, o conceito de Antropoceno ainda segue controverso: os geólogos não estão ainda convencidos de que a ação humana sobre a terra tenha contribuído para alterações estratigráficas a ponto de justificar a mudança de nome da época atual. Reza a voz hegemônica da comunidade internacional de geólogos que a espécie humana e toda a biosfera seguem vivendo no

\footnotetext{
* Professor da Universidade Federal da Bahia (UFBA). Doutorado em História das Ciências pela Fundação Oswaldo Cruz (FIOCRUZ). Email: andrecarvalho63@gmail.com
} 
Holoceno. Isso não impediu, porém, que o Antropoceno ganhasse vida própria, se tornando um conceito "guarda-chuva" capaz de articular uma rede internacional de pesquisadores mobilizados pela preocupação com a crise socioambiental planetária, constituindo, atualmente, um campo investigativo prolífico (FERRÃO, 2017). Em contraste com os geólogos, que nadam nas águas do mainstream de seu campo, os integrantes dessa abrangente e heterogênea rede de investigadores, pensadores e outros atores sociais já vivem, respiram e fazem pesquisa no e do Antropoceno.

Há uma miríade de abordagens temáticas e interpretativas do Antropoceno. Desde os estudos mais disciplinares até abordagens inter, multi ou transdisciplinares. Desde estudos mais críticos, que encaram com grande preocupação e senso de urgência a época atual, marcada pela crise climática decorrente do Aquecimento Global, afirmando a importância de uma desaceleração significativa e em curto prazo da pegada de carbono das nações de todo o mundo até os proponentes do chamado "bom Antropoceno", entusiastas dos avanços tecnológicos e do chamado "capitalismo verde", que encaram com otimismo os tempos em que vivemos, defendendo que as tecnologias limpas já existentes e as por vir serão capazes de garantir a sustentabilidade em nível planetário. Para estes, não há nada de errado com os caminhos tomados pela Civilização Ocidental ou com o Capitalismo. A mesma tecnologia e a mesma avidez que trouxeram a nós e ao planeta até o atual estado de coisas se encarregarão de prover as soluções. A mesma mentalidade que criou os venenos haverá de criar os antídotos, sem precisar impor à economia mundial qualquer tipo de desaceleração, sendo o bastante a reformulação das mesmas velhas práticas a partir de novas técnicas (FERRÃO, 2017).

A aderência às teses e agendas do "bom Antropoceno", no entanto, não é majoritária - ainda bem - entre os estudiosos dos problemas epistemológicos e práticos, por assim dizer, relacionados a esse conceito e suas implicações. Quer se encontrem envolvidos com discussões mais disciplinares e especializadas, quer abracem aproximações transdisciplinares de abrangência temática mais ampla e/ou difusa, a maioria dos estudiosos do Antropoceno tende a convergir para o entendimento do Antropoceno como resultado de uma atuação ambientalmente desequilibrada da agência humana sobre o planeta. Agência que precisa ser repensada e reformulada com urgência, antes que os efeitos antrópicos sobre o corpo do planeta alcancem proporções irreversíveis, com consequências drásticas ou mesmo catastróficas para os ecossistemas e para a própria viabilidade da sobrevivência da humanidade. Dentre os efeitos deletérios da crise climática gerada pela ambição desenfreada da agência humana se destaca o que os estudiosos têm chamado de "sexta grande extinção em massa". Diferentes eventos geológicos e/ou climáticos de grande intensidade foram responsáveis, até o presente momento, por extinções súbitas de grandes números de espécies ou mesmo grupos taxonômicos maiores inteiros, ou quase inteiros. O exemplo mais conhecido do grande público é o evento de extinção do Cretáceo-Paleógeno, ocorrido há cerca de 66 milhões de anos, quando se estima terem sido extintos três quartos de toda a vida vegetal e animal sobre a Terra, com destaque para os dinossauros. O momento atual, no entanto, tem a peculiaridade de ser a primeira vez na história do 
planeta que um evento de extinção de grandes proporções é causado pela ação de uma única espécie a humana.

\section{AS ESTRELAS: ANTROPOCENO, SOBERBA COLONIAL E ECOLOGIA DE SABERES}

Partindo da leitura do Antropoceno como problema, do Antropoceno como uma época de desequilíbrio na balança dos jogos de forças e agências da Terra, é preciso compreender que pensar o Antropoceno é e deve ser pensar em como chegamos ao Antropoceno, e quais guinadas precisamos dar como atores para a superação do Antropoceno, para que seja restituída à multiplicidade de agências do planeta a autoria do próximo período geológico. Pensar o Antropoceno é, ou deveria ser, pensar o fim do Antropoceno. Afinal, a menos que abracemos o negacionismo climático ou o otimismo do capitalismo verde, é preciso entender que o Antropoceno está, por assim dizer, com os dias contados. De um modo ou de outro, para o bem ou para o mal. Seja porque a incompetência dos agentes que são os principais responsáveis pela emergência do Antropoceno tenderá a levar a humanidade a ser engolfada pela onda da Sexta Grande Extinção, seja porque a humanidade venha a ser capaz de um grande pacto global, assumindo um protagonismo funcional sensato e sensível, capaz de reverter as lesões que vêm causando na carne do mundo e do vivo.

Quando dizemos - como sugere o próprio radical antropo no conceito de "Antropoceno" que a humanidade é responsável pelo desequilíbrio ecológico em nível planetário que hoje se dá, é preciso problematizar essa afirmação. De que "humanidade" estamos falando? É possível, correto ou justo colocar na conta de todos os povos e culturas do mundo a responsabilidade pelo estado atual de coisas? É sensato responsabilizar igualmente a camada de população que vive sob padrões de consumo extremamente elevado de bens e serviços, de um lado, e as camadas que vivem abaixo da linha da pobreza, de outro? É correto colocar no mesmo nível os moradores dos grandes centros urbanos e os habitantes de comunidades autossustentáveis de vida simples - vilarejos onde se pratica a pesca de subsistência, aldeias indígenas ou comunidades quilombolas que vivem em relação harmoniosa com a floresta? Pode-se comparar o dano feito ao mundo por pequenos empreendedores ao causado por grandes empresas predadoras da água e do solo, como alguns sabemos ser o caso de certos fabricantes de refrigerantes, engarrafadores de água e gigantes do agronegócio? É claro que não. Essa noção de um antropos universal mascara a existência e as diferenças de uma imensa variedade de atores, com papéis diversos - e, com frequência, opostos - na produção dos males antropocênicos. ${ }^{1}$ Entre os dois

\footnotetext{
1 Muitos autores envolvidos nos estudos do Antropoceno apontam a inadequação do termo por seu universalismo, que distribui uniformemente a toda a espécie humana (anthropos) a responsabilidade pelo atual desequilíbrio ambiental planetário. Inspirados em estudos críticos em história, antropologia e ciências sociais, políticas e econômicas, além dos estudos de Decolonialidade, esses autores propõe para designar a época atual nomes alternativos, que não negam a responsabilidade humana sobre o estado de coisas atual, mas que focam na responsabilização dos reais grupos e regimes. Como exemplos de tais nomes temos as ideias de Capitaloceno, que atribui a crise antropocênica ao desenvolvimento do capitalismo e Plantatioceno, que foca o drama ambiental nos sistemas de plantations. Entretanto, o nome Antropoceno parece já ter se afirmado, o que não significa que os estudiosos do Antropoceno não incluam tais críticas históricas, políticas e sociais em suas análises das dinâmicas do período atual (Cf. HARAWAY, 2016).
} 
extremos se situam, em um polo, o grande capitalista, o latifundiário da soja e da pecuária, o grileiro e o madeireiro mais violentos e, do outro lado, os povos ameríndios e quilombolas, cujos modos de vida lhes asseguram uma atuação de guardiões - quer voluntários, quer não - da biodiversidade florestal. Entre esses dois extremos há todo um espectro de posições possíveis, que inclui a de cada um de nós que lê ou escreve o presente ensaio.

Se é verdade que não podemos ser todos nós, humanos, igualmente implicados na responsabilidade pela antropocena em que hoje vivemos, por outro lado, somos todos necessariamente implicados na responsividade à situação que se nos apresenta. Se o ameríndio e o quilombola ocupam historicamente e efetivamente um lugar muito mais próximo ao de vítima do que de algoz na crise socioambiental planetária, nem por isso é dada a eles a opção de lavar as mãos, dizendo: "Vocês que são brancos que se se entendam". Em primeiro lugar, porque não existe lado de fora no planeta para onde se possam retirar. Em segundo lugar, porque são eles os mais imediatamente prejudicados pelos desastres ambientais que já principiam e os desastres piores que se anunciam. Em terceiro lugar, porque é neles, os detentores de saberes outros, que residem as chances e as esperanças - se é que ainda é possível usar essa palavra sem cair em um vazio retórico - de uma reviravolta. Nesse terceiro aspecto, talvez o nome generalista Antropoceno se justifique, se pensarmos que a o termo antropo, que designa toda a espécie humana, pode também ser encarado como um "chamado às armas". Se é o Homo occidentalis, com seu estilo de vida consumista, seu projeto moderno-colonial e sua invenção do capitalismo e do desenvolvimentismo, o principal responsável por ter desequilibrado o jogo de força das agências plurais do mundo vivo, a tarefa de responder às mazelas antropocênicas na direção de uma transformação profunda precisa cooptar todos os povos e culturas humanos. São os povos que aprenderam a se mover no compasso dos ritmos do mundo vivo que melhor podem capitanear esse movimento, com sua sabedoria ancestral. Para esclarecer essa afirmação, sirvo-me de um trecho de uma canção:

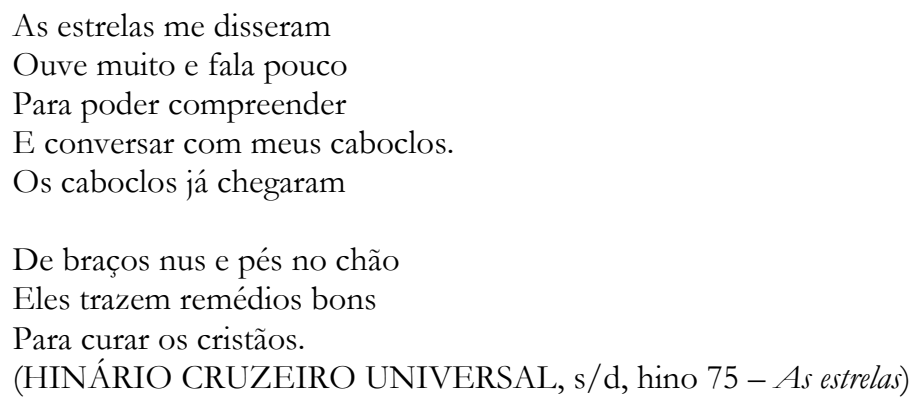

As estrelas é um hino recebido espiritualmente por Raimundo Irineu Serra, o Mestre Irineu, um homem negro de quase dois metros de altura que, na década de 1930, fundou no estado do Acre uma religião sincrética, que mescla elementos do cristianismo popular, da encantaria maranhense - terra de origem do Mestre - e das práticas indígenas de uso ritualístico de plantas de poder. Tendo sido iniciado, a partir do contato com indígenas e vegetalistas, no uso da ayahuasca - decocção que remonta 
aos povos andinos, preparada a partir da mistura de uma folha -, a chacrona ou rainha da floresta (Psychotria viridis) e um cipó, o jagube ou mariri (Banisteriopsis caapi), Irineu teve uma visão. Nessa "miração", conforme o jargão daimista, uma entidade feminina (que mais tarde se revelaria como Nossa Senhora da Conceição) o orientou a fundar no seio da comunidade onde vivia, à beira da Floresta Amazônica, uma nova religião. Seguindo as instruções desse ser divino, Irineu rebatizou a bebida sagrada com o nome de "daime". Nascia assim o Santo Daime, primeira religião ayahuasqueira do Brasil2 ${ }^{2}$ que tinha como propósito propiciar um caminho espiritual e de cura dos males físicos de seus praticantes e de todos mais que viessem a bater à porta da casa do Mestre.

O que importa para o escopo do presente ensaio não é traçar uma história, e muito menos discutir a teologia ou a liturgia inerentes ao Santo Daime. O que me proponho a analisar aqui é como a letra do hino supracitado - As Estrelas - ilustra e informa o debate sobre a abordagem que pretendo explorar nos estudos do Antropoceno, dando ênfase à questão da escuta. Para essa análise, uma ferramenta conceitual importante é a noção de "Ecologia de Saberes", do sociólogo português Boaventura de Sousa Santos. Crítico contumaz do epistemicídio decorrente da imposição dos saberes eurocêntricos pelo projeto uniformizante da Modernidade, Santos defende a importância de valorização do que chama de "Epistemologias do Sul", em oposição às epistemologias do Norte, eurocentradas (SANTOS; MENEZES, 2010). O "Sul” a que se refere, há que se compreender, não é o sul geográfico propriamente dito, mas o que o intelectual português chama de "Sul global" - um conjunto heterogêneo de atores e coletivos historicamente silenciados, que pode incluir desde os povos ameríndios aos bosquímanos africanos e aborígenes australianos, desde colônias de pescadores no litoral do Nordeste brasileiro a moradores das periferias no México ou mesmo trabalhadores das minas em uma cidade europeia. Da mesma maneira, o "Norte global" de Santos não obedece necessariamente aos contornos do Norte geográfico. Inclui a maioria dos habitantes das principais capitais da Europa e América do Norte, mas não as pessoas simples de Cuba, nem os imigrantes que vivem em situação de precariedade nos EUA, e pode, por outro lado, incluir as elites socioeconômicas da América do Sul. As epistemologias do Sul a que Santos se refere, portanto, são as epistemologias desenvolvidas por esses diversos povos e coletivos subalternizados e oprimidos. O autor propõe uma ecologia de saberes que contemple os conhecimentos das rezadeiras e benzedeiras, os chás que nossas avós aprenderam com suas avós, as técnicas de pesca e caça dos povos indígenas, seus mitos

\footnotetext{
2 São três as religiões ayahuasqueiras consideradas tradicionais no Brasil: o Santo Daime, fundado por Raimundo Irineu Serra na década de 1930; a Barquinha, fundado por Daniel Pereira de Matos, o Frei Daniel, que deixou o Santo Daime, com as bênçãos do Mestre Irineu, para, em 1945, difundir a própria doutrina; o Centro Espírita Beneficente União do Vegetal, ou simplesmente União do Vegetal, fundada por José Gabriel da Costa, o Mestre Gabriel, na década de 1960. Também tem importância na história das religiões ayahuasqueiras brasileiras a figura de Sebastião Mota, o Padrinho Sebastião, que, com a morte do Mestre Irineu, deixou com alguns seguidores o Alto Santo e fundou uma nova vertente do Santo Daime, ainda mais sincrética, incorporando práticas e elementos da umbanda, como a incorporação de médiuns, em seus rituais. O Santo Daime que se expandiu pelo país e pelo mundo é o do Padrinho Sebastião. O Santo Daime original persiste, existindo unicamente na igrejinha do Alto Santo, em Rio Branco. Existem várias outras pequenas igrejas que também se intitulam Santo Daime, sem filiação formal a nenhuma dessas casas. Atualmente o uso religioso da ayahuasca é permitido por lei, havendo, além das religiões ayahuasqueiras tradicionais, centenas de espaços neoxamânicos que fazem uso da mesma bebida, com rituais os mais diversificados.
} 
fundadores, suas cosmovisões e sua cosmopolítica, a ginga dos capoeiristas, as canções de ninar tradicionais, a cultura oral dos vilarejos, as epistemologias afromatizadas dos povos de santo do candomblé e da umbanda. Uma ecologia de saberes que contemple até mesmo os saberes acadêmicos, os saberes eurocêntricos que o projeto da Modernidade insiste (ou insistia?) afirmar serem os únicos que valem e os únicos que importam. Uma ecologia de saberes onde os conhecimentos produzidos pela Ciência Moderna têm vez, sim, mas não como voz única, nem como voz principal. Essa forma de ler o mundo abre espaços de interlocução entre as epistemologias hegemônicas do Norte e as epistemologias, até então subjugadas, do Sul (SANTOS; MENEZES, 2010).

Esse espaço dialógico que se abre, todavia, é e precisa ser, acima de tudo, um espaço de escuta. É nessa chave interpretativa que podemos, agora, olhar novamente para o hino As Estrelas. "Ouve muito e fala pouco para poder compreender e conversar com seus caboclos". Não é o caboclo, o homem da terra, o aborígene, o indígena que precisa escutar o homem branco, o homem do Ocidente. Ao contrário, é o homem branco, o homem que se autoproclama civilizado, quem precisa ouvir o caboclo. " "Os caboclos já chegaram de braços nus e pés no chão. Eles trazem remédios bons para curar os cristãos". Subvertendo a lógica missionária, não são aqui os missionários e cristãos, trajando batinas ou ternos e sapatos de couro lustrosos, em tudo estrangeiros à paisagem da floresta, que trazem a palavra de salvação para os caboclos. São os indígenas descalços que trazem para os cristãos da cidade grande a cura que vem das medicinas da floresta. Sem essa abertura do cristão que se cala para ouvir o caboclo, o indígena, sem esse norte de uma escuta humilde e atenta às vozes do Sul, o projeto epistemológico de uma abordagem do Antropoceno focada na ecologia de saberes se perde, porque se trai no mais básico dos princípios que o balizam - o princípio decolonial. A mínima distração que nos afaste desse fio vermelho orientador pode jogar por terra esse projeto investigativo e reflexivo, fazendo-o desembocar em uma recaída na soberba vaidosa das ortodoxias acadêmicas, na arrogância professoral e pastoril dos colonizadores.

A arrogância do homem moderno pode se apresentar em multifacetadas manifestações, das mais grosseiras, óbvias e de intentos explícitos até as mais ardilosas, em que o próprio agente do projeto colonial não se vê como tal. Pode ser o pastor missionário imbuído do propósito de evangelizar os povos indígenas nas aldeias. Pode ser o pesquisador de formação em ciências biológicas ou biomédicas que, das alturas da torre de marfim de seu palácio neopositivista, desdenha dos saberes populares e das cosmovisões ameríndias e afromatizadas. Pode ser um político honestamente progressista e humanista que abraça de forma acrítica um projeto de crescimento nacional a partir de um desenvolvimentismo tecnológico e econômico truculento - que mesmo que sensível às pautas de justiça social, econômica e racial, permanece insensível à urgência das questões ambientais. Todos esses

\footnotetext{
33 "Caboclo" é um termo polissêmico. Na música das modinhas de viola do interior do Sudeste e Sul do Brasil, é o homem do campo, o "caipira" que se autonomeia "caboclo". Numa acepção que é mais presente nos livros didáticos e dicionários do que verdadeiramente na cultura, caboclo é o mestiço de branco com indígena. $\mathrm{Na}$ umbanda e religiosidades afins, como o catimbó e a encantaria maranhense, os caboclos são na maioria das vezes falanges de espíritos ou encantados indígenas. Uma vez que O Mestre Irineu era de origem maranhense, e com base na própria descrição que seu hino faz dos caboclos, é mais do que razoável supor que a referência diz respeito a indígenas.
} 
atores - alguns, inclusive, com visões de mundo em muitos aspectos antagônicas e mutuamente hostis - participam do mesmo projeto colonial, pois uma linha histórica e ideológica costura todas essas posturas. É a linha da soberba colonial, da arrogância espistêmica dos que se consideram os detentores dos conhecimentos verdadeiros. Essa linha rege os saberes proclamados como palavra divina inquestionável por um religioso fundamentalista a brandir a dita Bíblia Sagrada. Essa linha rege também os saberes chancelados, confirmados e conformados no borbulhar dos cadinhos nem sempre tão alquímicos dos laboratórios, altares do templo da Ciência Moderna, onde não faltam normas litúrgicas que decidem e definem quais ideias e visões deverão receber o status de verdade e quais devem ser tratadas como mentiras e crendices - ou mesmo de heresias, quando tais ideias se propõem a desafiar os cânones que delineiam as fronteiras epistêmicas de um dado campo disciplinar acadêmico.

\section{O BEBÊ E A ÁGUA DA BACIA: MODERNIDADE, COLONIALIDADE E DECOLONIALIDADE}

Em tempos como os atuais há que se fazer uma ressalva. Testemunhamos, com uma sensação de indignação impotente, o avanço de uma onda de obscurantismo político e moral, apoiado em um negacionismo histórico e científico que se alastra, estendendo seus tentáculos nas agendas e agências dos Estados, invariavelmente entrelaçados com ideologias ultraconservadoras, intolerantes e totalitárias (agendas estas às quais os interesses ultraliberais do mais voraz capitalismo dão as mãos sem hesitação, vergonha ou escrúpulos sempre que entendem que a implantação de tais pautas favorecem sua ganância irrefreada). Por isso é importante frisar que não se trata aqui de adotar uma perspectiva ingênua que atribua, por exemplo, a uma visão criacionista o mesmo poder explicativo de uma abordagem evolucionista nos debates sobre a origem da vida. Não se trata aqui de propor igual status de verdade a pesquisas sólidas e opiniões arbitrárias, ou colocar em pé de igualdade um jornalismo sério e uma corrente de fake news. Não se trata aqui de renegar as tradições, métodos e contribuições da Ciência Moderna, nem mesmo de virar as costas para as conquistas sociais e civilizatórias que vieram a reboque da Modernidade e do projeto iluminista. Não se trata aqui de jogar fora o bebê junto com a água da bacia, mas sim de reconhecer que a água da bacia está suja, muito suja. Trata-se de reconhecer no projeto da Modernidade o projeto da Colonialidade como rio subterrâneo da arrogância supremacista eurocentrada do Homo occidentalis. Um supremacismo que, ao longo dos cinco a seis séculos de sua instalação, submeteu e segue submetendo os povos originários da África, Ásia, Oceania e Américas a seu projeto civilizatório - de início de bases alegadamente cristãs, e atualmente de bases alegadamente seculares. Um rio subterrâneo em cujo lodo floresceu e floresce o mais brutal capitalismo, em conformidade com as agendas coloniais de ocupação, subjugação, exploração, genocídio, etnocídio e epistemicídio. É nessas águas subterrâneas que se alinham o pastor neopentecostal missionário e o cientista positivista ateu, o megaempresário predador e o político 
progressista que encara a questão ambiental e a questão indígena como transtornos no caminho de seu projeto desenvolvimentista.

Walter Mignolo se refere ao rio subterrâneo da Colonialidade como "o lado mais sombrio da Modernidade" (MIGNOLO, 2017). Se há um rio subterrâneo deve-se supor a coexistência de um rio que corre às claras e às vistas de todos os olhos. Se a Modernidade tem um lado mais sombrio, é razoável supor que haja, igualmente, um lado onde incide a luz, sem ocultações. Há pelo menos duas maneiras possíveis de encararmos essa relação da Modernidade com a Colonialidade. Uma dessas interpretações - mais radical, polarizada e compreensivelmente ressentida - seria a de que todos os supostos valores e conquistas do projeto da Modernidade e da Civilização Ocidental nunca passaram de fachadas para as agendas da Colonialidade. Outra forma, mais moderada e ponderada, é que as faces mais vistosas do projeto da Modernidade podem ter sido - e com frequência e malícia de fato foram usadas como fachada para o avanço dos intentos coloniais, mas que, de todo modo, nesse caldo histórico-cultural da Modernidade emergiram realizações tecnológicas, epistemológicas e científicas que beneficiaram ou, ao menos, têm grande potencial de beneficiar quantos povos humanos venham a se interessar por eles e a eles ter o acesso franqueado ou conquistado - desde que não por coerção. Noções como a de direitos humanos, por exemplo - no que pesem as críticas e problematizações no que se refere à sua pretensa universalidade - são hoje base e estandarte de luta social e reivindicações pelos mais diferentes coletivos humanos historicamente subalternizados - mulheres, negros, população LGBTQIA+, povos ameríndios, entre tantos outros. O próprio ensaio aqui apresentado, por exemplo, é submetido a um periódico acadêmico, para ser avaliado por pares acadêmicos e, uma vez aprovado, lido principalmente por indivíduos com formação ou em processo de formação acadêmica. É um texto escrito em um computador, e que será enviado e - caso avaliado positivamente - disponibilizado via internet a leitores de língua portuguesa que podem se encontrar em qualquer ponto do globo terrestre. Tudo isso são feitos da Modernidade. Além disso, esse texto articula conceitos em grande parte - mas não unicamente - concebidos por autores acadêmicos, mesmo que incluam - como de fato incluem críticas às ortodoxias acadêmicas. Trata-se, aqui, portanto, não de defender o silenciamento ou a extinção do conjunto inteiro das obras e conquistas do Homo occidentalis, mas da importância de que esse Homo occidentalis possa fazer silêncio e dar vez e ouvidos às vozes que a babel cacofônica do Antropoceno insistiu e ainda insiste em calar. Ouvir muito e falar pouco, para poder compreender e conversar com os caboclos.

\section{A VIRTUDE MÍOPE DO HUMANISMO}

Se é possível, como dito acima, fazer uma crítica ao projeto da Modernidade lançando mão de parte do instrumental conceitual nascido no seio dessa mesma Modernidade, isso não significa que essas ferramentas, mesmo que úteis e até importantes, sejam bastantes em si. Tais ferramentas se 
revelam insuficientes porque míopes. ${ }^{4}$ Antropocentrismo, é esse o nome da virtude míope do humanismo. Mesmo o humanismo revolucionário, mesmo o humanismo mais sinceramente comprometido com a reparação das injustiças sociais, raciais e de gênero, mesmo o humanismo comprometido com uma crítica contundente ao etnocentrismo e com a valorização da diversidade dos povos, culturas e saberes humanos - mesmo esse humanismo não escapa das constrições impostas por tal miopia. A miopia das lentes valorativas que só enxergam as formas e só ouvem as vozes humanas. A miopia antropocêntrica é fardo, lastro e âncora da miopia antropocênica. Alimenta e sustenta uma tradição de conveniências ideológicas. Como em um dito atribuído a Hermann Hesse, "é admirável como nossas tendências sempre dão um jeito de se disfarçar de filosofia." O antropocentrismo é um excelente e deplorável exemplo dessas 'filosofias' ardilosas do Homo occidentalis para legitimar seu domínio sobre todos os demais corpos - desde humanos a animais, vegetais e o próprio corpo de Gaia.

Destaca-se, dentro do corpus antropocêntrico, a doutrina do excepcionalismo humano - a ideia de que a espécie humana (em especial o macho branco europeu e seus herdeiros históricos) é detentora de propriedades, capacidades cognitivas ou dotações espirituais que lhe conferem um status singular de destaque e superioridade dentre todas as demais formas de vida. Status este que lhe garante um direito natural de subjugar os demais viventes a seus propósitos, e em nome desses interesses explorar sem restrições as matas, cerrados, a água, o subsolo, os oceanos, tudo que compõe o corpo do mundo. Se a noção de excepcionalismo humano remonta à Antiguidade - possivelmente emergindo ou, ao menos, se acentuando quando do florescimento das primeiras grandes religiões monoteístas - é no seio e no nascedouro da Modernidade que essa doutrina tem seu apogeu. Francis Bacon, com sua Nova Atlantida (BACON, 2001 e René Descartes, com seu cogito ergo sum (DESCARTES, 1979), têm especial relevância como patronos dessa visão.

O avanço, lento e progressivo, do projeto da Modernidade desde um pensamento de base cristã até um pensamento de contornos seculares não foi acompanhado, por contraditório que seja, por significativas mudanças nessa doutrina central da miopia antropocêntrica. Para entendermos como o excepcionalismo humano contribui para o problema epistemológico do Antropoceno é preciso que examinemos brevemente a história de como a Ciência Moderna encara os animais. Em Descartes, um dos grandes patronos da Modernidade, os animais (não-humanos) eram meros autômatos orgânicos insensíveis, e mesmo seus gritos, quando feridos, eram reações mecânicas, não envolvendo sofrimento verdadeiro, pois dentre todas as formas vivas somente a humana seria dotada de uma alma imortal. Mas houve Darwin. Se o darwinismo propôs ou impôs ao edifício da Ciência Moderna uma visão de mundo que prescinde da necessidade da existência de um Criador onipotente para explicar a origem da vida e a existência dos seres, se o darwinismo tinha e tem esse poder de golpear a vaidade do Homo

\footnotetext{
4 A escolha aqui das palavras "míope" e "miopia" não desconsidera nem desdenha dos problemas relativos ao capacitismo. Sustento, contudo, a opção por tais palavras como metáfora descritiva da condição fisiológica da miopia: a dificuldade de foco.
} 
occidentalis, destronando-o, do ponto de vista biológico, de seu lugar de herdeiro ou jardineiro de Deus, nos terrenos epistemológico e ontológico mais amplos e, principalmente, no terreno axiológico, o excepcionalismo humano segue se agarrando com força e fúria onde pode para não perder seu posto e seu vigor. Com o processo de secularização das ciências naturais e humanas em curso, a antropologia física e a paleoantropologia apostaram na tese do "rubicão cerebral", a linha divisória baseada na capacidade craniana. $\mathrm{O}$ aumento do tamanho cerebral marca o momento em que o processo de hominização transportou o primeiro de nossos ancestrais hominídeos de um estado de animal, sujeito aos ditames de sua biologia, a homem, que deixava para trás os grilhões de sua natureza biológica para se tornar um ser de cultura (GEERTZ, 1989, p. 41-61). Com isso, o animal humano deixava, na prática, de ser um animal - ou, ao menos de se comportar como tal. Se o triunfo da tese darwiniana da origem comum e parentesco universal entre os homens e os demais seres vivos roubava, ao menos por um curto lapso de tempo, do Homo sapiens ${ }^{5}$ o status de filho dileto de Deus, eis que a tese antropológica do rubicão cerebral lhe restituía esse status, trocando apenas a posse de uma alma imortal pelo conceito de cultura como atributo exclusivo da humanidade.

Se Charles Darwin afirmava e argumentava, com numerosas evidências baseadas no comportamento dos animais não humanos, que "a diferença entre os homens e os [demais] animais é uma diferença de grau, e não de tipo", recebendo reforço nos estudos de seu seguidor e aliado George Romanes, não demorou para que viessem os neodarwinistas a explicar que calma, não é bem assim. A começar, já no apagar das luzes do século XIX, por Conwy Lloyd Morgan, que formulou o famigerado "cânone de Morgan", que dita que todo comportamento animal deve ser explicado a partir da interpretação mais simplista e menos complexa possível. Nascia a escola associacionista, que procurava explicar todo o comportamento animal aprendido a partir de fórmulas reducionistas do tipo estímuloresposta - visão que teria seu corolário no behaviorismo de John Watson e, mais tarde, de Burrhus Skinner. Roubando do animal darwiniano original sua inteligência, sagacidade, emotividade e complexidade, os neodarwinistas recuperavam, assim, o animal cartesiano. Em nome do rigor científico, sob o pretexto - em parte justificável, há que se admitir - de enxugar dos animais de Darwin e Romanes as projeções antropomórficas existentes nas interpretações feitas por esses autores, na prática o movimento que começava com Morgan e que sobrevive até hoje, em conformidade e ressonância com o rubicão cerebral dos paleoantropólogos, devolvia ao ser humano seu status de único animal racional. $\mathrm{O}$ animal darwiniano original, inteligente e sensível, sofria uma espécie de lobotomia epistemológica que lhe devolvia à condição prévia de autômato orgânico insensível, uma versão 2.0 do animal cartesiano (CARVALHO, 2014).

A partir da década de 1960, o animal darwiniano começaria seu lento renascimento, com os estudos de longa duração das primatólogas Jane Goodall, Dian Fossey e, cerca de uma década depois,

\footnotetext{
${ }^{5}$ Note-se, na escolha do naturalista Lineu, a pujança da arrogância da Modernidade: Homo sapiens - homem sábio. Com apenas duas palavras se nomeava uma espécie inteira com uma base sexista, submetendo as mulheres à espécie "homem", e se proclamava sábio justamente esse homem moderno, que já caminhava em passos largos na implantação das agendas coloniais de exploração e subjugação dos povos não-ocidentais e de todas as formas de vida não-humanas.
} 
Biruté Galdikas. Investigando em campo, respectivamente, os chimpanzés (Pan troglodytes) e gorilas da montanha (Gorilla beringei beringei) nas selvas africanas e os orangotangos (Pongo pygmaeus) nas selvas de Bornéu, as 'trimatas' mostraram ao mundo científico animais de uma complexidade comportamental insuspeitada. As três tinham o mesmo mentor intelectual: Louis Leakey, um eminente antropólogo interessado em conhecer melhor o comportamento dos nossos três parentes mais próximos ${ }^{6}$, de modo a fazer projeções sobre o comportamento de nossos ancestrais hominídeos. Interessante aqui é que, no caso das duas primeiras de suas pupilas, Leakey - um renomado pesquisador com sólida formação científica - escolheu para essa tarefa duas pessoas sem formação em ciências naturais. Jane Goodall era então uma jovem de 20 e poucos anos que nem sequer tinha um diploma de graduação, apenas um curso de secretariado. Dian Fossey, devido a dificuldades financeiras, havia desistido de um curso de medicina veterinária e se formado como terapeuta ocupacional. Ambas, contudo, haviam procurado independentemente o grande antropólogo por terem forte interesse na pesquisa com animais. Leakey, por sua vez, as escolheu em parte em decorrência do entusiasmo de ambas, mas também porque queria dar prioridade a pesquisadores que não estivessem demasiado dominados por convicções prévias sobre as coisas das quais um animal era capaz - ou, principalmente, as coisas das quais um animal não era capaz (uma vez que para tais propósitos Leakey escolheu três mulheres, em uma época em que o universo da ciência era francamente dominado por homens, é razoável supor que também queria evitar o viés da percepção masculina sobre as capacidades animais).

A partir dos esforços pioneiros de Goodall e Fossey - e, mais tarde, de Galdikas - e do florescimento, também no início da década de 1960, da Etologia Cognitiva de Donald Griffin, o animal darwiniano passava a experienciar, assim, uma reafirmação ontológica. Esse parto não foi fácil nem sem dor, e, mesmo nos dias atuais, em grande parte dos pesquisadores das ciências humanas e nas correntes de uma ortodoxia decadente no campo da Etologia, ainda vemos narizes se torcerem diante de quem atribui racionalidade e emoções aos animais. Evitam-se expressões como "mente" ou "inteligência”, dando-se preferência a termos mais neutros, como "cognição". Entretanto, já existem pesquisadores de vanguarda com grande prestígio entre os pares, como os primatólogos Frans de Waal e Barbara Smuts, que defendem abertamente a legitimidade de se falar em emoções e inteligência animais, entre outros atributos. A tese do rubicão cerebral também parece estar a viver seus estertores. A doutrina do excepcionalismo humano, contudo, é insidiosa. Seus tentáculos se alastram por todas as práticas e empreitadas do Homo occidentalis, desde as grandes fazendas industriais, onde animais "de corte" são criados em condições aviltantes, até as mesas dos laboratórios, onde criaturas sencientes são sacrificadas "pelo bem da ciência", em experimentos com frequência aterradores e nem sempre tão facilmente justificáveis em prol das demandas de aumento no conhecimento das ciências biomédicas. Sem falar da indústria da peleteria, que cria em gaiolas mínimas animais inteligentes e sensíveis, como

\footnotetext{
${ }^{6}$ Naqueles tempos pouco ou nada se conhecia sobre o bonobo (Pan paniscus), parente imediato do chimpanzé, e junto a este, o parente biológico vivo mais próximo da espécie humana.
} 
as raposas e visons, para nada mais que a satisfação estética e ostentação social dos consumidores que podem se dar ao luxo de possuir e exibir um casaco de pele.

\section{A PERSPECTIVA MULTIESPÉCIES}

Nessa empreitada necessária para além das constrições do humanismo se destaca a abordagem multiespécies dos estudos do Antropoceno. Visceralmente anti-antropocêntrica, estabelece, entre seus princípios basilares, uma vigorosa crítica a dois dos pilares epistemológicos da Modernidade: o excepcionalismo humano e dicotomia natureza-cultura. Natureza e cultura deixam de ser polos de um par antitético, e se afirmam como um continuum que tudo abrange. Não natureza versus cultura, e sim natureza-cultura - ou, talvez, ainda melhor, naturezacultura, para que o hífen não arrisque a dar a falsa sensação de separação. A epistemologia que subjaz e informa esse olhar é a de que não existem "seres de natureza", de um lado, e "seres de cultura" de outro. Tampouco a cultura é vista como uma emergência cognitiva sofisticada e tardia de seres que eram de início entidades meramente biológicas, a cultura como uma culminação da trajetória histórico-evolutiva que teria conferido a seus privilegiados portadores uma espécie de alforria dos grilhões de sua condição natural pregressa. Sob a ótica da perspectiva multiespécies pode-se dizer que toda forma de ser é também uma forma de conhecer. Toda forma de existir no mundo é também, e necessariamente, uma forma de ler o mundo. Se olharmos para o mundo dessa perspectiva, veremos que a biosfera é também uma epistemosfera. Mais uma vez, para evitarmos a separação, podemos falar de um bioepistemosfera, que abriga uma sociobiodiversidade que deve ser preservada e defendida com unhas, dentes, sangue, suor e garras.

A antropóloga Anna Tsing, um dos maiores expoentes dos estudos multiespécies do Antropoceno, sustenta a importância de que seu campo disciplinar se expanda na edificação de uma "antropologia-mais-que humana" (TSING; MATHEWS; BUBANDT, 2019). Servindo-nos desse valoroso sufixo, se levarmos às últimas consequências a perspectiva multiespécies, é preciso que todo o edifício das Ciências como as conhecemos se abra ao desafio ousado da des-modernização. Recorro a essa expressão aqui não no sentido de defesa de algum recuo ao pré-moderno, nem de uma incursão vazia de desconstrução pós-moderna, mas no sentido condizente com a proposta de Tsing: a expansão dos saberes acadêmicos tradicionais para um olhar que não se detenha no humano. A adesão à abordagem multiespécies requer que possamos pensar não só em uma antropologia, mas também em uma história-mais-que-humana, uma sociologia-mais-que-humana, uma filosofia-mais-que-humana e até mesmo, por redundante que soe, em uma biologia-mais-que-humana. Pois se é verdade que as ciências biológicas têm, inescapavelmente, o conjunto de todos os seres vivos como objetos de seus estudos, também é verdade que somente em raras exceções os seres vivos não-humanos são encarados e respeitados como sujeitos. A biologia que hoje se pensa e pratica costuma se sentir e se assentar de forma obscenamente confortável não apenas nos cânones modernos, mas também em seus correspondentes coloniais - o que é outra maneira de dizer que, salvo alguns pontos fora da curva, a 
Biologia Moderna segue firme e determinada em sua agenda investigativa e epistemológica antropocêntrica, sem apresentar quaisquer sinais de desconforto com sua adesão à doutrina (sim, a palavra é essa) do excepcionalismo humano. Desde os animais não-humanos usados como modelos experimentais, submetidos a condições de vida degradantes sem maiores questionamentos das implicações e complicações éticas desse emprego, até os grandes biomas planetários, toda vida nãohumana é encarada como recurso. As matas e oceanos são coleções de recursos naturais, a paixão pelos animais é, acima de tudo, uma paixão epistemológica - mais uma vez, o animal como recurso: objeto de pesquisa e conhecimento. Insta-se à importância de preservação e recuperação de áreas ambientais ameaçadas ou degradadas, mas não porque as florestas, o cerrado ou a caatinga sejam encaradas como entidades detentoras de valor inerente, mas sim de valor instrumental. A vida nãohumana nos vale na medida em que nos serve - seja como recurso para alimentar a glutonaria das fornalhas do Capitalismo, seja como reserva para garantir nossa sobrevivência e a das gerações (humanas) futuras. Então, sim, faz-se necessário pensarmos uma biologia-mais-que-humana para que possamos enfrentar os desafios do Antropoceno.

No olhar da abordagem multiespécies a vida é um fenômeno que se tece continuamente, os seres vivem emaranhados em múltiplas teias de interdependência. Nessa obra coletiva e incessante da teia múltipla dos viventes, todas as espécies são, por assim dizer, portadoras de virtudes tecelãs - todas são dotadas de agência. Essa agência-mais-que-humana implica que todo tornar-se é sempre "tornar-se com" (becoming with) (HARAWAY, 2007), pois o fenômeno do vivo é relacional. Novos tipos de relações estão sempre a emergir, formando alianças não-hierárquicas, vínculos simbióticos, entrelaçamentos de criaturas criativas. A espécie humana não é protagonista principal de coisa alguma - ou, ao menos, não deveria ser. Nessa chave, é possível pensar o Antropoceno como uma era de usurpação, quando uma espécie - ou, sendo mais precisos e mais justos - quando um coletivo especialmente barulhento e voraz de uma espécie se arrogou o direito de protagonizar a cena do mundo vivo, reencenando a hubris mitológica na violação do corpo de Gaia, submetendo, ou tentando submeter, todas as demais criaturas a seus intentos e à sua fome de mundo. O Homo occidentalis parece sofrer da ilusão profunda de que é possível e de que tem sido bem-sucedido até aqui esse projeto de domínio absoluto, de subjugação completa da natureza (o que implica, é claro, a adesão à ilusão de que existe uma natureza fora de si, da qual seja destacado). A atual pandemia parece até vir nos lembrar que não é bem assim que as coisas se dão. Um vírus é um tipo de entidade tão simples estruturalmente que os cientistas têm dificuldade para decidir se deve ser encarado como um ser vivo ou não. Entretanto, é uma entidade com essa identidade ontológica límbica que tem submetido a espécie humana a um conjunto de transtornos, sofrimentos, incertezas e morte. A emergência dessa entidade do seio de uma selva asiática, ganhando proporções pandêmicas em função de um desequilíbrio ambiental de origem antrópica, reafirma a interdependência da teia múltipla do vivo e nos relembra - ou deveria relembrar que a espécie humana, nem mesmo em suas versões mais tecnologicamente poderosas, tem o domínio soberano sobre todas as espécies do planeta. A vida começou na Terra na forma de microorganismos. 
Cada célula nossa abriga dezenas de bactérias - o que significa que temos mais bactérias que células "humanas" no corpo. A despeito do fato de que a espécie humana assumiu um poder de agência sobre o planeta que lhe confere, talvez, o status de uma força geológica, a despeito do aquecimento global antrópico e da Sexta Grande Extinção que vem em seu bojo, pode-se afirmar, sem medo de erro, que se é que existe alguma forma de vida que domine a Terra, essa forma de vida são os microorganismos em especial, as bactérias. Como disse Lynn Margulis, "a vida é bactéria” (MARGULIS; SAGAN, 1995, p. 90).

\section{A ESCUTA DOS POVOS PRIMEIROS: TRANSDISCIPLINARIDADE E ANIMISMO}

Se queremos aprender a nos mover no Antropoceno e para além do Antropoceno, precisamos aprender a nos co-mover, ouvindo as vozes para as quais os ouvidos modernos sempre se fizeram surdos. E se nos propomos a ouvir todas as vozes que precisam ser ouvidas no Antropoceno é preciso nos permitirmos um passo para além da disciplinaridade, e mesmo da inter ou multidisciplinaridade. Se nos propomos a uma escuta humilde dos problemas e atores do Antropoceno é preciso nos permitirmos incursões para além dos jogos interativos entre os conhecimentos e epistemologias disciplinares, além das fronteiras dos cânones disciplinares. Somente abraçando a transdisciplinaridade essa escuta é possível, em compromisso com uma Ecologia de Saberes e uma visão decolonial que ousem transcender as barreiras ontológicas, epistemológicas e axiológicas do humanismo. É na transdisciplinaridade que as múltiplas vozes do Antropoceno podem ecoar e escoar sua pluralidade de sentidos.

Em uma entrevista ao portal da Associação Nacional de Pós-Graduação e Pesquisa em Educação (ANPEd) - e Revista Brasileira de Educação (RBE), por ocasião da 39ª Reunião Nacional da ANPEd, em outubro de 2019, Boaventura de Sousa Santos declarou:

\footnotetext{
Agora o que eu digo é o seguinte: a ciência não é o único conhecimento válido, há outros conhecimentos válidos que têm que ser validados por seus próprios méritos. Ou seja, se eu quero ir à Lua, eu preciso do conhecimento científico, se eu quero conhecer a biodiversidade da Amazônia eu tenho que conhecer o conhecimento dos indígenas e das populações ribeirinhas. São elas que conhecem a biodiversidade da Amazônia. (SANTOS, 2019)
}

Note-se acima a ressonância da fala de Santos com o hino espiritual do Mestre Irineu, a instar os cristãos a dar ouvidos ao que os caboclos têm a lhes dizer e a lhes trazer. Dito de outra forma, na exploração transdisciplinar e decolonial das múltiplas vozes do Antropoceno é essencial escutarmos o que têm a dizer os povos primeiros, os povos originários, aqueles cujos sistemas de saberes lhes possibilitavam e ainda possibilitam caminhar sobre o mundo sem ferir de morte a carne do mundo.

Um aspecto epistemológico central ao pensamento plural dos povos originários parece residir no que os antropólogos decidiram chamar de animismo. A noção de animismo, as cosmovisões animistas pressupõem um mundo que é vivo por inteiro. Da teia múltipla dos viventes até as rochas, as 
águas dos rios, a luz do Sol - em tudo há vida, e tudo é vida. Ouçamos os próprios pensadores indígenas a esse respeito. O xamã yanomami Davi Kopenawa explica que "a floresta é inteligente, ela tem um pensamento" (KOPENAWA; ALBERT, 2015, p. 497). Essa inteligência da floresta está inextricavelmente ligada ao fato de ela ser um ente vivo:

Os brancos pensam que a floresta foi posta sobre o solo sem qualquer razão de ser, como se estivesse morta. Isso não é verdade. Ela só é silenciosa porque os espíritos xapiripë detêm os entes maléficos e a raiva dos seres da tempestade. Se a floresta fosse morta, as árvores não teriam folhas brilhantes. Tampouco se veria água na terra. [...] A terra da floresta possui um sopro vital, wixia, que é muito longo. O dos seres humanos é muito menor: vivemos e morremos depressa. Se não a desmatarmos, a floresta não morrerá. Ela não se decompõe. É graças a seu sopro úmido que as plantas crescem. Quando estamos muito doentes, em estado de espectro, ele também ajuda na nossa cura. Vocês não veem, mas a floresta respira. Olhem para ela: suas árvores estão bem vivas e suas folhas brilham. Se ela não tivesse sopro, as árvores estariam secas. Esse sopro vem do fundo da terra, lá onde repousa seu frescor. Ele também está em suas águas (ALBERT; MILLIKEN; GOODWIN-GOMEZ, 2009, p. 7)

\section{PALAVRAS QUE ABRAM OLHOS E MUNDOS}

A noção animista, leitura do mundo como mundo vivo, também está presente nos povos ameríndios do Hemisfério Norte. Robert Macfarlane, escritor britânico que aborda o Antropoceno de forma transdisciplinar, chama a atenção de seus leitores para o idioma dos Potawatomi, nativos americanos da região das Grandes Planícies. Em seu idioma, 70\% das palavras são verbos - em contraste com os apenas 30\% de verbos no idioma inglês. "Quase todas as palavras", afirma o autor "declaram o estado animado ou inanimado daquilo a que se referem". Como exemplos, cita dois vocábulos: Puhpowsee, que é "a força que faz os cogumelos emergirem da terra da noite para o dia", e Wiikwegamaa, que significa ser/estar sendo uma baía. Macfarlane cita Robin Wall Kimmerer, uma pensadora do povo Potawatomi:

Uma baía é um substantivo apenas se a água estiver morta, aprisionada entre as rochas da praia, contida pela palavra que a nomeia. Mas o verbo [...] liberta a água desse aprisionamento e a deixa viva. "Estar sendo uma baía" mantém a maravilha de que, durante esse momento, a água viva decide se abrigar nesses rochedos, em conversação com as raízes de cedro e os bebês mergulhões (MACFARLANE, 2019, p. 93)

Refletindo sobre a linguagem dos Potawatomi, e sobre o quanto esta influencia é influenciada pela sua cosmovisão, Macfarlane afirma que "a linguagem é uma das grandes forças geológicas do Antropoceno", motivo pelo qual defende a importância de que pensemos uma nova gramática, uma "gramático do animado" (animacy), constitutiva de uma "linguagem predisposta a reconhecer vida na alteridade e estender a categoria "vida" muito além dos limites do pensamento ocidental" (MACFARLANE, 2019, p. 93), com o poder de trazer à tona um mundo mais-que-humano. Não é de

7 "To be a bay", no original em inglês.

Pol. Hist. Soc., Vitória da Conquista, v. 20, n. 1, p. 170-191, jan.-jun. 2021. ISSN 2236-8094 
hoje que os estudiosos de humanidades se debruçam sobre essa questão: as palavras não são meras ferramentas descritivas da realidade externa e das realidades subjetivas. As palavras têm agência. As palavras têm a capacidade de fechar e de abrir olhos e mundos. Fazendo coro a Macfarlane, precisamos de novas palavras, de palavras capazes de abrir olhos, palavras capazes de inaugurar novos mundos, novas formas de vivermos e compartilharmos a experiência do mundo.

Algumas dessas "novas" palavras são, na verdade, muito antigas, oriundas de culturas milenares, como é o caso dos vocábulos usados pelos Potawatomi. São novas, contudo, aos nossos olhos de Homo occidentalis, e grande pode ser sua potência para abrir mundos. Outras são palavras antigas aplicadas de novas formas, como o conceito de Gaia, nome da deusa primordial que personificava a Terra na mitologia grega, para designar o planeta Terra como um grande sistema complexo, sinérgico e autorregulado (LOVELOCK, 1972). Não é indiferente chamarmos o planeta em que vivemos de "Terra" (ou "Sistema Terra") ou o chamarmos de Gaia. Gaia remete a um superorganismo, a um mundo vivo. Da mesma forma, nos referimos às formas vivas como "organismos" ou "seres vivos" não provoca em quem ouve o mesmo efeito ou impacto de quando nos referimos a esses seres como "viventes". Viventes dão a ideia de processo, a ideia de seres que habitam um verbo vivo, seres em devir. Um ser vivo será provavelmente uma entidade que se move nos territórios concretos da Modernidade, respeitando as muralhas paradigmáticas neopositivistas e mecanicistas de um neodarwinismo que está sempre a se remodelar no contato com novos desenvolvimentos científicos, mas sem jamais desafiar de fato a doutrina do excepcionalismo humano, que impõe antolhos ao olhar do pesquisador. Seres vivos são máquinas de sobrevivência e reprodução. Sua morfologia, fisiologia e comportamento (quer inato, quer aprendido) não servem a quaisquer propósitos outros que os de atender aos imperativos biológicos adaptativos determinados por seus "genes egoístas". Os viventes, por sua vez, não são de todo livres de tais pressões evolutivas, que contribuem significativamente para o desenho de suas formas e as propensões de sua conduta. Nem por isso, contudo, essas forças e mecanismos encerram todas as possibilidades e capacidades de um vivente. Nas palavras de Jacob von Uexküll, um biólogo da primeira metade do século XX que já mal se fazia ouvir, mas cujas concepções vêm hoje sendo revisitadas com vigoroso interesse, cada vivente é não a máquina [ou não apenas a máquina], mas o maquinista [ou também o maquinista], sujeito da própria existência (UEXKÜLL, 1933). Um organismo, neodarwinisticamente programado e constrangido, é um ser cujo funcionamento e conduta obedecem invariável e inescapavelmente a uma regra de custo versus benefício, focada e centrada exclusivamente no estratégico, no pragmático, no utilitário. Um vivente, por sua vez, respeita tais propensões, mas nelas não se detém.

Sob as lentes míopes da Ciência Moderna, o líder de um grupo de gorilas da montanha (Gorilla beringei beringei) a conduzir seu grupo pelas trilhas da mata se reduz a um "macho alfa", detentor e monopolizador de recursos genéticos, imbuído de forma inconsciente do propósito único de gerar a prole o mais numerosa e bem-sucedida possível, em nome do sucesso reprodutivo de seus genes. Os filhotes que dele se aproximam para formar laços sociais mais próximos são motivados por um 
interesse biológico de expandir seu status no grupo (ROSENBAUM et al, 2015) - quase como se esses gorilas neodarwinistas, esses gorilas-organismo tivessem lido Bordieu. Um gorila-vivente, porém, tem motivações mais abrangentes. Nessa espécie o costas-prateadas não é simplesmente o animal mais poderoso, por assim dizer, do bando; ele é também um dos mais sábios. Conhece os tempos de frutos das árvores em cada trilha, conhece as variedades de caminhos. Sabe onde encontrar pedras com sais minerais, nutrientes escassos, mas ricos ao grupo. Lidera o grupo pelas sendas, protege-os de predadores. O filhote gorila vivente não vê no macho costas-prateadas simplesmente ou acima de tudo um indivíduo ao qual é competitivamente vantajoso se associar; vê-o também - ou, quem sabe, principalmente - como uma espécie de mentor (LENTS, 2016), pelo qual se interessa porque o admira. Pois, diferentes dos "organismos", os viventes são mais, muito mais que meros sobreviventes. São também desejantes, brincantes, expectantes, criativos e criadores. Experimentam, como nós humanos, prazer e dor, alegria, fúria, confusão, dúvida, assombro. Exercitam sua coragem, no conflito constante entre medo e desejo. Cantam e fazem algazarra, executam coreografias de cortejo e exibições de força para impressionar parceiros sexuais potenciais e intimidar rivais, sim, mas também porque têm "um eu a expressar" (LESTEL, 2002, p. 217), porque lhe faz bem dar vazão a seus anseios de celebração do gozo de existir. Exploram novos territórios porque a expansão territorial aumenta suas chances de reprodução, ampliando seu acesso aos recursos do ambiente. Entretanto, assim como os povos ameríndios vivem em uma floresta viva, que não se resume a uma coleção de recursos, tampouco os viventes se relacionam com o mundo vivo como se este se reduzisse a seu valor instrumental. Exploram o horizonte de possibilidades do mundo não apenas para assegurar seu sucesso genético, mas porque têm sede do novo, têm avidez por vivenciar a riqueza plural do vivo.

Se dizemos "a biodiversidade do planeta Terra" ou dizemos "a teia múltipla dos viventes em Gaia" estamos e não estamos dizendo a mesma coisa, pois um "como" também fala de um "quê", também porta um "quê". As palavras que escolhemos para nomear ou renomear o mundo em que vivemos provocam em quem as ouve uma resposta não apenas sensorial e imagética, mas também afetiva. Afetiva, aqui, na acepção mais primitiva da palavra - afetar-se, permitir-se ser afetados. Ouçamos, mais uma vez, um pensador indígena brasileiro, o guarani Kaká Werá Jecupé:

Há que se ter coragem de silenciar diante de uma paisagem. Há que se ter coragem para conversar com um rio. Há que se ter a ousadia de agradecer à terra por tudo que ela dá. E quem tiver coragem e ousar, verá o quanto fomos medíocres diante desta beleza (JECUPÉ, 2002, p. 94).

Essa é a coragem que nos é exigida para que possamos ultrapassar o Antropoceno na direção de um Bioceno, de um Simbioceno: a coragem de nos abrirmos para a possibilidade de sermos afetado pelo outro - um outro que tanto é radicalmente distinto em sua constituição sociobiopistemológica, como também é conosco irmanado por um parentesco ancestral que remonta à origem da vida orgânica em Gaia e por uma coparticipação em interdependência na teia multicêntrica dos viventes. Aqui é outro o desafio das palavras: é preciso que renunciemos às atribuições antropocêntricas 
humanistas costumeiras, estendendo o uso de algumas palavras para além das fronteiras do humano. Se queremos dar vez às vozes que precisam ser ouvidas no Antropoceno é preciso abrirmos nossos

ouvidos e ampliarmos nossa escuta. É preciso ouvir as vozes dos povos da floresta. Se nos propomos a ouvir as vozes dos povos da floresta, temos que ouvir as vozes flecheiras, as vozes ribeirinhas, as vozes quilombolas... mas, ao mesmo tempo, entender que sim, ouvir esses povos muito importa, mas não basta, pois a expressão encerra muitos outros viventes. Povos da floresta são também os povos alados, os povos de escamas, os povos aquáticos, os povos que se rastejam e se escondem na serrapilheira ao pé das árvores centenárias, os povos insetos, os povos vegetais.

Se queremos de fato ouvir as múltiplas vozes do Antropoceno, é preciso que a própria ideia de ouvir e respeitar os mais velhos se estenda para além da escuta atenta aos anciões humanos como mananciais de sabedoria e inclua também a escuta das vozes que já se faziam ouvir muitos séculos antes do advento dos povos primatas na superfície do planeta. Ouvir as vozes dos agentes e agências que o Antropoceno silenciou e segue silenciando é abrir os ouvidos à escuta de Gaia. Gaia como corpo vivo, como mundo vivo e vibrante, como entidade pulsante em sua miríade de formas e vozes. Vozes que sibilam, vozes que ciciam, vozes que urram e rosnam e bufam. Vozes que cantam em gorjeios, trinados, pios, assobios. Vozes que cricrilam, vozes que coaxam. Vozes que ululam nas horas escuras. Vozes que entoam cânticos ultrassônicos na imensidão dos oceanos. Escutar as sinfonias selvagens das múltiplas vozes dos viventes.

\section{ANIMISMO E ENCANTAMENTO}

Luiz Antônio Simas é um pensador que respira transdisciplinaridade. Escritor, professor e historiador, compositor brasileiro e babalaô no culto de Ifá, Simas estuda, entre outros temas, o samba, o Carnaval e o imaginário da umbanda, encantaria e outras formas de expressão e vivência da religiosidade dos grupos historicamente marginalizados no Brasil. O pedagogo Luiz Rufino vem empreendendo estudos com uma abordagem bastante próxima, e recentemente os dois autores começaram a publicar alguns estudos em uma prolífica parceria.

Proponentes de conceitos heterodoxos como "epistemologia da macumba" e "pedagogia das encruzilhadas", Simas e Rufino defendem a necessidade de se pensar uma "ciência encantada" (Cf. SIMAS; RUFINO, 2019 e SIMAS; RUFINO, 2019). "Encantar", afirmam os autores, "é expressão que vem do latim incantare, o canto que enfeitiça, inebria, cria outros sentidos para o mundo". A perspectiva do encantamento é central ao trabalho de Simas, que, explorando o universo imaginário das tradições populares e culturas religiosas evocativas das entidades chamadas de "encantados", observa: "O contrário da vida não é a morte, o contrário da vida é o desencanto (SIMAS; RUFINO, 2020, p. 11)". Destacam, assim, a força desse olhar como forma de enfrentamento das matrizes coloniais de dominação: 
O encantamento dribla e enfeitiça as lógicas que querem apreender a vida em um único modelo, quase sempre ligado a um senso produtivista e utilitário. Daí o encante ser uma pulsação que rasga o humano para o transformar em bicho, vento, olho d'água, pedra de rio e grão de areia, o encante pluraliza o ser, o descentraliza, o evidenciando como algo que jamais será total, mas sim ecológico e inacabado (SIMAS; RUFINO, 2020, p. 9).

Os ditos encantados - Zé Pelintra, Maria Padilha e demais pombas giras, os erês (espíritoscriança), as pretas e pretos velhos, os caboclos e caboclas da Umbanda, da Encantaria e do Catimbó juremeiro - são entidades identificadas com os marginalizados, os proscritos, os tipos humanos historicamente subalternizados que, no giro epistêmico das giras e mandingas, se afirmam como corpos subversivos. A potência epistemologicamente transformadora do processo do encante diz respeito a seres que, ao driblar a não-vida, a antivida, saltam da condição de "sobras viventes", ultrapassam a posição de sobreviventes e se afirmam ontologicamente como "supraviventes" (SIMAS; RUFINO, 2020, p. 6) Movendo-se nas frestas e brincando nas brechas do projeto colonial que busca domar os corpos, os encantados, simplesmente por serem, conspiram contra a Modernidade, que insiste em silenciar a biossociodiversidade.

Falamos do encantamento enquanto astúcia de batalha e mandinga em um mundo assombrado pelo terror. Enquanto há quem ache que é bobagem e as florestas são derrubadas, os xamãs e pajés invocam os espíritos na natureza para recordarem que um dia fomos árvore, folha e poeira do universo. Virados no transe de medicinas que desconhecemos, eles miram a cura para esse adoecimento. (SIMAS; RUFINO, 2020, p. 8)

Davi Kopenawa Yanomami, em sua contrantropologia A Queda do céu, também fala desse poder do encantamento em sua trajetória individual em meio ao seu povo até se tornar um xamã. Iniciado pelo sogro no uso do pó da árvore yãkoana, uma planta psicoativa, Davi entra em contato com os xapiri. Criados, como tudo o mais, por Omama - o homem primordial, uma espécie de demiurgo dos yanomami - os xapiri são seres espirituais que dançam para os xamãs e, com o poder de sua dança, impedem que o céu caia sobre a terra. É esse jogo anímico de encantamento que envolve homens, animais, plantas e entidades do invisível da mata em uma ciranda de espiritualidade selvagem ${ }^{8}$, na qual o pensador ameríndio é capaz de escutar e ser escutado, deixar-se afetar e ser agente afetivo e efetivo. $\mathrm{Na}$ teia de relações anímicas e míticas que mobiliza e pela qual é mobilizado, o xamã, a partir de um conhecimento que não apreende por vias meramente intelectuais, mas em uma vivência profundamente corporificada, compreende o verdadeiro valor da floresta.

Tudo o que cresce e se desloca na floresta ou sob as águas e também todos os xapiri e os humanos têm um valor importante demais para todas as mercadorias e o dinheiro dos brancos. Nada é forte o bastante para poder restituir o valor da

\footnotetext{
${ }^{8}$ Se o emprego termo "selvagem" já foi fortemente eivado de preconcepções e atribuições desvalorativas que marcavam seus detentores em uma posição de primitivo, inculto, insensível ao cultivo das virtudes e incapaz de raciocínio, hoje essa atitude vem se transformando. Em uma nova chave valorativa, pode-se pensar o selvagem em termos de uma sensibilidade e maior abertura sensorial ao mundo vivo que o cerca, o selvagem como indômito e livre, o selvagem como portador dos conhecimentos ancestrais que o projeto civilizatório desprezou e aos quais precisa se reconectar. Selvagem como adjetivo de profundamente vinculado aos ritmos das matas e ao pulsar de Gaia.
} 
floresta doente. Nenhuma mercadoria poderá comprar todos os Yanomami devorados pelas fumaças de epidemia. Nenhum dinheiro poderá devolver aos espíritos o valor de seus pais mortos! É por isso que devemos nos recusar a entregar nossa floresta... Seu valor é alto demais para ser comprada por quem quer que seja... O sopro de nossa vida vale muito mais! Para saber disso, não preciso ficar com os olhos cravados em peles de imagens, como fazem os brancos. Basta-me beber yãkoana e sonhar escutando a voz da floresta e os cantos dos xapiri (KOPENAWA; ALBER'T, 2015, p. 355).

Plenamente consciente de que o valor da floresta é acima de tudo intrínseco, e não instrumental, o xamã yanomami também percebe que o homem branco civilizado, explica Kopenawa, parece ter perdido a capacidade de ouvir o mundo vivo. Ele precisa da ajuda do homem da floresta para recuperar essa competência de escuta, sob o risco de que a permanência de sua insensibilidade aos clamores selvagens resulte em uma nova queda do céu:

Por isso quero mandar minhas palavras para longe. [...] Faz muito tempo que Omama e nossos ancestrais as depositaram em nosso pensamento e desde então nós as temos guardado. Elas não podem acabar. Se as escutarem com atenção, talvez os brancos parem de achar que somos estúpidos. Talvez compreendam que é seu próprio pensamento que é confuso e obscuro, pois na cidade ouvem apenas o ruído de seus aviões, carros, rádios, televisores e máquinas. Por isso suas ideias costumam ser obstruídas e enfumaçadas. Eles dormem sem sonhos, como machados largados no chão de uma casa. Enquanto isso, no silêncio da floresta, nós, xamãs, bebemos o pó das árvores yãkoana hi, que é o alimento dos xapiri. Estes então levam nossa imagem para o tempo do sonho. Por isso somos capazes de ouvir seus cantos e contemplar suas danças de apresentação enquanto dormimos. Essa é a nossa escola, onde aprendemos as coisas de verdade (KOPENAWA; ALBERT, 2015, p. 76-77).

As palavras de Kopenawa falam do preço alto que Homo occidentalis paga por suas escolhas, cheias de percursos e percalços de desconexão e desencantamento, e enfatiza que os yanomami não estão dispostos a incorrer no mesmo erro. Como disse antes o Mestre Irineu, também um homem da Floresta Amazônica, a escuta humilde da sabedoria dos povos originários e de todos os povos das matas - humanos ou não, materiais ou imateriais, encarnados ou encantados - é nossa melhor aposta, quiçá nossa única e última oportunidade, para a travessia das águas turvas e turbulentas do Antropoceno. Se o Homo occidentalis será capaz de tal humildade e tal coragem é uma questão em aberto. Se podemos confiar na História do homem moderno para tentar uma previsão, é razoável supor que as probabilidades não estão exatamente do nosso lado. Como agravante, se podemos confiar nas ciências do clima para tecer previsões razoáveis a respeito de algo tão complexo quanto a capacidade responsiva ou a resistência de Gaia à sanha insaciável do capitalismo e sua predatória e despudorada violação da carne do mundo, tudo indica que não nos resta muito tempo. Medidas significativas capazes são não apenas necessárias, mas também urgentes. Por outro lado, não nos faltam sólidos pontos de referência - vozes a ouvir, exemplos a seguir, mitos e valores potentes capazes de nortear os passos trôpegos do homem moderno pelos caminhos sinuosos e promissores das virtudes selvagens. 


\section{REFERÊNCIAS}

ALBERT, B.; MILLIKEN, W.; GOODWIN-GOMEZ G. Uribi A, A terra-floresta yanomami. São Paulo: Instituto Socioambiental; Institut de Recherche pour le Développement, 2009.

BACON, F. New Atlantis. New York: Bartleby.com, 2001.

CARVALHO, A. L. L. Simpatia para além dos confins do homem: as origens animais da inteligência e da sensibilidade e suas implicações éticas nas relações entre humanos e não-humanos. In: MORAES, J. Q. de (org.). Materialismo e Evolucionismo III. Campinas: Unicamp, 2014. p. 59-96. (Coleção CLE, v. 65).

CRUTZEN, P. J.; STOERMER, E. F. The “Anthropocene”. Global Change Nensletter n. 41, p. 17-18, 2000.

DESCARTES, R. Discurso do método. São Paulo: Abril Cultural, 1979.

FERRÃO, J. O Antropoceno como narrativa: uma lente útil para entender o presente e imaginar o futuro? Biblos, 3, p. 205-221, 2017.

GEERTZ, C. A Interpretação das Culturas. Rio de Janeiro: Zahar, 1989.

HARAWAY, D. J. When Species Meet. Minneapolis; London: University of Minnesota Press, 2007.

HARAWAY, D. J. Antropoceno, Capitaloceno, Plantationoceno, Chthuluceno: fazendo parentes. ClimaCom, n. 5, p. 139-146, 2016.

HINÁRIO CRUZEIRO UNIVERSAL, s/d, hino 75 - As estrelas.

JECUPÉ, K. W. Oré Até roiru'a ma - todas as vezes que dissemos adeus. São Paulo: Fundação Phytoervas, 2002.

LENTS, N. New Research Characterizes Mountain Gorilla "Friendships". The Human Evolution Blog, Jan 25, 2016. Disponível em: https://thehumanevolutionblog.com/2016/01/25/new-researchcharacterizes-mountain-gorilla-friendships/

KOPENAWA, D.; ALBERT, B. A queda do céu: palavras de um xamã Yanomami. Trad. de Beatriz Perrone-Moisés. São Paulo: Companhia das Letras, 2015.

LESTEL, D. As origens animais da cultura. Lisboa: Instituto Piaget, 2002.

LOVELOCK, J. E. Gaia as seen through the atmosphere. Atmospheric Environment, v. 6, n. 8, p. 579580, 1972.

MACFARLANE, R. Underland: A Deep Time Journey. New York; London: W.W. Norton \& Company, 2019.

MARGULIS, L; SAGAN, D. What is Life? New York: Simon and Shüster, 1995.

MIGNOLO, W. D. Colonialidade: o lado mais escuro da modernidade. Rev. Bras. Ci. Soc. [online]. 2017, v. 32, n. 94, e329402. Epub June 22, 2017. ISSN 1806-9053. Disponível em: https://edisciplinas.usp.br/pluginfile.php/5540723/mod_resource/content/1/MIGNOLO $\% 2 \mathrm{C} \% 20$ Walter.\%20COLONIALIDADE $\% 2 \mathrm{C} \% 20 \mathrm{O} \% 201 \mathrm{lado} \% 20$ mais $\% 20$ escuro $\% 20 \mathrm{da} \% 20$ modernidade.pdf 
ROSENBAUM, S. et al. Relationships Between Adult Male and Maturing Mountain Gorillas (Gorilla beringei beringę) Persist Across Developmental Stages and Social Upheaval. Ethology, v. 122, n. 2, p. 134150, 2015.

SANTOS, B. S. Entrevista com Boaventura de Sousa Santos, conferencista de abertura da $39^{a}$ Reunião Nacional da ANPEd. 14 de outubro de 2019. Disponível em: https://www.anped.org.br/news/entrevista-com-boaventura-de-sousa-santos-conferencista-deabertura-da-39a-reuniao-nacional-da

SANTOS, B. S.; MENESES, M. P. (org.) Epistemologias do Sul. São Paulo, Cortez. 2010.

SIMAS, L. A.; RUFINO, L. Fogo no mato: a ciência encantada das macumbas. Rio de Janeiro: Mórula Editorial, 2019.

SIMAS, L. A.; RUFINO, L. Encantamento: sobre politica de vida. Rio de Janeiro: Mórula Editorial, 2020.

TSING, A. L.; MATHEWS, A. S.; BUBANDT, N. Patchy Anthropocene: Landscape Structure, Multispecies History, and the Retooling of Anthropology. Current Anthropology, v. 60, p. S186-S197, 2019.

UEXKÜLL, J. von. Dos animais e dos homens: digressões pelos seus mundos próprios, doutrina do significado. Lisboa: Livros do Brasil, 1933. 